\title{
Gene Expression and Carcass Traits Are Different between Different Quality Grade Groups in Red-Faced Hereford Steers
}

\author{
Bailey Engle ${ }^{1}\left(\mathbb{D}\right.$, Molly Masters ${ }^{2}$, Jane Ann Boles ${ }^{2}$ and Jennifer Thomson ${ }^{2, * \mathbb{D}}$ \\ 1 Centre for Animal Science, Queensland Alliance for Agriculture and Food Innovation, \\ St. Lucia, QLD 4072, Australia; b.engle@uq.edu.au \\ 2 Department of Animal and Range Sciences, Montana State University, Bozeman, MT 97071, USA; \\ molly.masters@montana.edu (M.M.); jboles@montana.edu (J.A.B.) \\ * Correspondence: Jennifer.thomson@montana.edu; Tel.: +1-40-(69)-947434
}

check for updates

Citation: Engle, B.; Masters, M.;

Boles, J.A.; Thomson, J. Gene

Expression and Carcass Traits Are Different between Different Quality Grade Groups in Red-Faced Hereford Steers. Animals 2021, 11, 1910. https://doi.org/10.3390/ani11071910

Academic Editor: Michael Hässig

Received: 19 May 2021

Accepted: 23 June 2021

Published: 27 June 2021

Publisher's Note: MDPI stays neutral with regard to jurisdictional claims in published maps and institutional affiliations.

Copyright: (C) 2021 by the authors. Licensee MDPI, Basel, Switzerland. This article is an open access article distributed under the terms and conditions of the Creative Commons Attribution (CC BY) license (https:/ / creativecommons.org/licenses/by/ $4.0 /)$.
Simple Summary: Producing a consistent and positive experience for beef consumers is challenging. The gene expression in muscle at harvest may provide insight into better prediction of United States Department of Agriculture (USDA) quality grade. In this pilot study muscle samples were collected at harvest on sixteen steers with a similar background and identical management. Muscle transcripts were sequenced to determine gene expression. Transcripts related to the extracellular matrix, stem cell differentiation, and focal cell adhesions were differentially expressed in muscle tissue from carcasses with differing USDA quality grades. This confirmed the application of this technique to provide insight into muscle development and fat deposition necessary for better prediction and selection to improve consistency and consumer experience.

Abstract: Fat deposition is important to carcass value and some palatability characteristics. Carcasses with higher USDA quality grades produce more value for producers and processors in the US system and are more likely to have greater eating satisfaction. Using genomics to identify genes impacting marbling deposition provides insight into muscle biochemistry that may lead to ways to better predict fat deposition, especially marbling and thus quality grade. Hereford steers (16) were managed the same from birth through harvest after 270 days on feed. Samples were obtained for tenderness and transcriptome profiling. As expected, steaks from Choice carcasses had a lower shear force value than steaks from Select carcasses; however, steaks from Standard carcasses were not different from steaks from Choice carcasses. A significant number of differentially expressed (DE) genes was observed in the longissimus lumborum between Choice and Standard carcass RNA pools (1257 genes, $p<0.05$ ), but not many DE genes were observed between Choice and Select RNA pools. Exploratory analysis of global muscle tissue transcriptome from Standard and Choice carcasses provided insight into muscle biochemistry, specifically the upregulation of extracellular matrix development and focal adhesion pathways and the downregulation of RNA processing and metabolism in Choice versus Standard. Additional research is needed to explore the function and timing of gene expression changes.

Keywords: gene expression; quality grade; beef cattle

\section{Introduction}

Subcutaneous fat thickness and marbling (intramuscular fat) are integral parts of the United States grading systems and are a large portion of the pricing system. Many certification systems, such as Certified Angus Beef ${ }^{\mathrm{TM}}$, are utilizing marbling to reduce variation in tenderness. These schemes are being developed because inconsistency of the tenderness in meat is a major concern in the beef industry due to reduced consumer acceptance [1]. Many researchers have indicated steaks from Prime and Choice carcasses were more tender than steaks from Select carcasses [2-4]. Consequently, providing consistent tender products has become a major concern for beef cattle producers. 
Subcutaneous fat is a major factor in the prediction of yield from a carcass, while marbling has been used to try and guarantee tenderness [5]. As time on feed increases, marbling and subcutaneous fat increase, leading to an increase in both the amount of subcutaneous fat and the number of carcasses grading USDA Choice [6]. Techniques that would allow us to better understand how fat deposition is controlled at the transcript level would help to reduce "overfeeding" and improve the efficiency of grain-fed beef production. Ongoing research is required in order to gain a better understanding of the genetic expression of these traits and how selection plays a role in the transmission and expression of these economically significant characteristics The development of high-throughput transcriptomic analysis has provided a powerful tool to study gene expression by allowing simultaneous measurement of the entire transcriptome [7-9], including mRNA, transcription factors, and gene-splicing variants that can impact gene activity. Combined with the traditional tools of physiology and biochemistry, a transcriptomic level of understanding will progress our knowledge of cell biology and bovine muscle biochemistry. Previous studies have evaluated gene expression in animals with varying degrees of fatness or intramuscular fat [10-12]. Many of these studies have focused on small sets of genes with a known function such as peroxisome proliferator-activated receptors (PPARs) and sterol regulatory element-binding proteins (SREBPs) [11,12]. The specific objective of this pilot study was to evaluate the relationship between USDA meat quality grade and gene expression to look for additional genes, pathways, and networks that relate to meat quality grade. This exploratory research provides an overview of gene expression changes in relation to quality grade within a cohort with a common genetic background, management, age, and days on feed.

\section{Materials and Methods}

Sixteen red-faced Hereford steers were fed at Fort Keogh Agricultural Research Station under the standard feedlot Standard Operating Procedures (SOP). These animals were genetically similar and were born within a three-week period and handled from birth through harvest as the same group with a common diet and management. All animals received care according to the "Guide for the Care and Use of Agricultural Animals in Agricultural Research and Teaching, 3rd Edition" and under the supervision of the Fort Keogh Animal Care and Use Committee (ACUC No.: 020104-9). Animals within the same cohort that produced carcasses grading Standard, Select, and Choice at the same age and days on feed were sampled for this study.

The animals were harvested after all steers had been fed in the same pen for 270 days in the feedlot. Animals were harvested at a federally inspected facility. At harvest, a muscle sample from the longissimus lumborum (LL) near the posterior end was collected using a Tru-cut biopsy needle [13], snap-frozen in liquid nitrogen, and stored for subsequent RNA extraction within $30 \mathrm{~min}$ following exsanguination. Carcass data were collected $24 \mathrm{~h}$ postmortem to calculate yield grade and determine quality grade following USDA guidelines [14]. Carcasses were ribbed between the 12th and 13th rib exposing the longissimus dorsi. Marbling determination was carried out a minimum of $20 \mathrm{~min}$ after ribbing to give time for the muscle to oxygenate. Carcass characteristics were measured by an individual with 25 years of experience in carcass data collection and the training of people to collect carcass data. USDA marbling standards were used to ensure the consistency of marbling scores. Physiological maturity of the carcass was assessed by evaluating the ossification of the bones in the vertebral column and evaluating lean color and the color and shape of the rib bones. Fat thickness was measured at the 12 th rib at a distance $3 / 4$ of the way from the spinal column towards the ventral side of the carcass with a metal ruler divided into 0.1 -inch increments. The measurements were later converted to $\mathrm{cm}$ for statistical analysis. The rib eye area was measured using a standard grid that had 10 dots per square inch, and dots surrounded by lean were the ones counted. The square inches measured with the grid were converted to square centimeters for statistical analysis. Internal fat was estimated as a percentage of the carcass weight. After $24 \mathrm{~h}$, striploins (North American 
Meat Purveyors-NAMP 180) were removed from the left side of each carcass. These striploins were cut into $2.54 \mathrm{~cm}$ steaks, vacuum packaged, and aged for 1, 3, 7, 14, and 21 days. These samples were used to determine shear force values for each steak.

The biopsy samples collected for RNA-seq analysis averaged $165 \mathrm{mg}$ of tissue. A Qiagen RNeasy spin-column kit was used for RNA extraction. Extracted RNA samples had an average concentration of $35.88 \mathrm{ng} / \mathrm{uL}$. RNA quality was assessed using an Agilent 2200 Tapestation and RNA Screentape. The RIN (RNA integrity) values averaged 7.06 with a minimum value of 6.7. The extracted RNA was depleted of ribosomal RNA using an Invitrogen Ribominus kit and then used to create individual cDNA libraries that were then randomly allocated to one of two pools for each quality grade of Standard, Select, and Choice. These pools were created to provide a biological replicate sample and to focus our pilot analysis on genes that were differentially expressed by quality grade and not due to individual animal variation. These pools were then sequenced on an Ion Proton next-generation sequencing platform according to the manufacturer's instructions. The sequencing reads generated were aligned to the known bovine consensus sequence (Btau 4.2), and a normalized count of reads was generated to determine the expression of each known gene and gene isoforms using Strand NGS RNA-seq software (version 2.8, Avadis, Bangalore, India). Differentially expressed genes and transcripts were calculated using a pooled z-test with a test statistic of

$$
\begin{gathered}
Z=\frac{\sqrt{\frac{x_{1}}{N_{1}}}-\sqrt{\frac{x_{2}}{N_{2}}}}{\sqrt{\frac{1}{4 N_{1}}+\frac{1}{4 N_{2}}}} \\
x^{1}=\sum_{i=1}^{q_{1}} x_{1}, x_{2}=\sum_{i=1}^{q_{2}} x_{2 i}, N_{1}=\sum_{i=1}^{q_{1}} N_{1 i} \text { and } N_{2}=\sum_{i=1}^{q 1} N_{2 i}
\end{gathered}
$$

and with $p$-values calculated by

$$
\begin{gathered}
\text { if } Z<0, p=2 * \Phi(Z) \\
\text { else } p=2 *(1-\Phi(Z)) \\
\text { where } x_{1}:
\end{gathered}
$$

A Bonferroni correction was used to account for multiple comparisons and determine a corrected $p$-value. Additionally, fold change between Standard and Choice, as well as up- and downregulation, was determined for a Standard vs. Choice comparison. Gene set enrichment analysis and network and pathway analysis were used to identify genes and gene networks that relate to growth rate, tenderness, and carcass quality. Functional analysis was performed using DAVID bioinformatics software (version 6.8, Frederick National Laboratory, Frederick MD, USA) [15]. Library preparation and bioinformatics analysis were conducted according to the SOP and pipeline developed at Colorado State University Infectious Disease Unit and published in Das et al. (2016) [16,17]. RNA-seq data can be accessed at 10.5281 /zenodo.4993828.

Shear force was determined using previously published methods [18]. Briefly, steaks were thawed at $4{ }^{\circ} \mathrm{C}$ for $24 \mathrm{~h}$, weighed, and two copper constantan thermocouples (Omega Engineering, Stanford, CT, USA) were inserted into the geometric center of each steak and placed under $(10 \mathrm{~cm}$ from element) an electric broiler and cooked to a final internal temperature of $70{ }^{\circ} \mathrm{C}$, turning when the samples reached $35^{\circ} \mathrm{C}$. Each steak was weighed before and after cooking to determine cook loss. Eight to ten square samples $(1.27 \mathrm{~cm} \times$ $1.27 \mathrm{~cm} \times 2.54 \mathrm{~cm}$ ) for shear force evaluation were removed parallel to the fiber direction from each steak that was cooked and cooled. Samples were sheared once perpendicular to the fiber direction with a TMS 30 Food Texturometer fitted with a Warner-Bratzler shear attachment. The average of the samples sheared was used for statistical analysis in relation to the differentially expressed genes and transcripts.

Individual animals were used as the experimental unit $(n=16 ; 6$-Choice, 5 -Select, 5-Standard). The Generalized Linear Model (GLM) procedure of SAS, Statistical Analysis 
System (Cary, NC, USA) was used to analyze carcass and tenderness data. Lease Square Means (LSMEANS) procedures of SAS were employed due to an unequal number of observations upon which to compare differences between variables. Interaction between aging time and treatment was tested. It was not significant, so the data were analyzed as independent variables.

\section{Results and Discussion}

There were significant differences in carcass characteristics between carcasses of different quality grades. As expected, marbling scores were significantly lower for Standard and Select carcasses. The hot carcass weight $(\mathrm{HCW})$ was significantly lower for Standard carcasses but was not different between Choice and Select carcasses. Ribeye area (REA) and kidney, pelvic, and heart fat percentage (KPH) were also significantly different between all three grades, with Choice having the largest REA and highest KPH and Standard the lowest (Table 1). Fat thickness, however, was not different between Choice and Select carcasses, while the Standard carcasses had less subcutaneous fat. Other researchers have reported relationships between larger carcasses and REA, as well as increased fat with larger carcass weights from concentrate-fed animals $[6,19,20]$. Fat deposition is a balance between energy consumed versus energy used. The steers were all of a very similar genetic background and chronological age and had been managed in a similar manner throughout their lifespan. Therefore, steers resulting in Standard-grade carcasses with a smaller REA and higher variability in REA suggests they had not completed muscle growth and were therefore using more energy for continued muscle growth and storing less fat [21-23]. Furthermore, Select and Choice carcasses had significantly higher yield grades than Standard carcasses, suggesting a lower percentage of closely trimmed retail cuts could be achieved from those carcasses.

Table 1. Main effect of quality grade on average shear force and carcass characteristics of red-faced Hereford steers.

\begin{tabular}{cccccccc}
\hline Grade & $\begin{array}{c}\text { Shear Force } \\
(\mathbf{N} \pm \mathbf{S D})\end{array}$ & $\begin{array}{c}\text { HCW } \\
\mathbf{( k} \pm \mathbf{S D g})\end{array}$ & $\begin{array}{c}\text { Fat } \\
\mathbf{( c m} \pm \mathbf{S D})\end{array}$ & $\begin{array}{c}\text { REA } \\
\left.\mathbf{( c m}^{\mathbf{2}} \pm \mathbf{S D}\right)\end{array}$ & $\begin{array}{c}\text { KPH } \\
\mathbf{( \%} \pm \mathbf{S D})\end{array}$ & $\begin{array}{c}\text { Yield Grade } \\
( \pm \mathbf{S D})\end{array}$ & $\begin{array}{c}\text { Marbling } \\
\mathbf{(} \pm \mathbf{S D})\end{array}$ \\
\hline Standard & $66.3^{\mathrm{b}} \pm 12.4$ & $250.6^{\mathrm{b}} \pm 33.0$ & $0.43^{\mathrm{b}} \pm 0.21$ & $57.68^{\mathrm{c}} \pm 5.27$ & $1.60^{\mathrm{c}} \pm 0.22$ & $2.46^{\mathrm{ab}} \pm 0.4$ & $266^{\mathrm{c}} \pm 16.7^{\mathrm{a}}$ \\
Select & $84.3^{\mathrm{a}} \pm 13.9$ & $282.9^{\mathrm{a}} \pm 23.0$ & $0.64^{\mathrm{a}} \pm 0.21$ & $67.23^{\mathrm{b}} \pm 2.72$ & $1.80^{\mathrm{b}} \pm 2.27$ & $2.62^{\mathrm{a}} \pm 0.37$ & $330^{\mathrm{b}} \pm 18.7$ \\
Choice & $71.3^{\mathrm{b}} \pm 13.0$ & $283.2^{\mathrm{a}} \pm 15.9$ & $0.58^{\mathrm{a}} \pm 0.23$ & $72.13^{\mathrm{a}} \pm 4.87$ & $2.08^{\mathrm{a}} \pm 0.38$ & $2.35^{\mathrm{b}} \pm 0.24$ & $463^{\mathrm{a}} \pm 15.0$ \\
$p$ value & $<0.0001$ & $<0.0001$ & 0.0104 & $<0.0001$ & $<0.0001$ & 0.0077 & $<0.0001$ \\
\hline
\end{tabular}

${ }^{1} 200=$ Traces, $300=$ Slight, $400=$ Small, $500=$ Modest. ${ }^{a}, \mathrm{~b}, \mathrm{c}$ means within the column with different superscripts are significantly different $p \leq 0.05$.

There was no significant interaction between carcass grade and days of aging for shear force. Therefore, main effect means are presented in Tables 1 and 2. Steaks from Standard and Choice carcasses had significantly lower average shear force values than steaks from Select carcasses (Table 1). Obuz et al. [3] also reported steaks from Select carcass being less tender than steaks from Choice carcasses, while Legako and coworkers [24] reported no difference in sensory tenderness scores for longissimus lumborum samples from different quality grades. Unfortunately, there is much less research on the tenderness of steaks from Standard-quality-grade carcasses, so there are much less data to compare these results with. In contrast, Smith et al. [25] and Tatum et al. [6] reported that sensory panel ratings increased, and shear force values decreased as the marbling score and fat thickness increased. The variation in reported tenderness information suggests that other factors are affecting tenderness along with the changes in intramuscular and subcutaneous fat. As expected, postmortem aging resulted in a decrease in shear value (Table 2) along with a reduction in variation within a sample [26-28]. The data reported here for shear force value are similar to other data reported when square cores were used to determine shear force $[18,19,29]$. 
Table 2. Main effect of aging on the shear force of steaks from red-faced Hereford steers.

\begin{tabular}{cc}
\hline $\begin{array}{c}\text { Age } \\
\text { (days) }\end{array}$ & $\begin{array}{c}\text { Shear Force } \\
\text { (N } \pm \text { SD) }\end{array}$ \\
\hline 1 & $89.9^{\mathrm{a}} \pm 16.5$ \\
3 & $80.7^{\mathrm{b}} \pm 17.8$ \\
7 & $71.0^{\mathrm{b}} \pm 13.7$ \\
14 & $65.3^{\mathrm{b}} \pm 11.9$ \\
21 & $62.9^{\mathrm{c}} \pm 9.7$ \\
\hline
\end{tabular}

$\overline{a, b, c}$ Means within the column with different superscripts are significantly different $p \leq 0.05$.

In this exploratory study, there were a significant number of differentially expressed (DE) genes (1257 genes, $p<0.05)$ in LL muscle tissue from Choice and Standard carcasses and a similar number (1249 genes, $p<0.05)$ between LL muscle tissue from Choice and Select carcasses. There were also a significant number of DE genes (2376 genes, $p<0.05)$ between LL muscle from Select and Standard carcasses. The complete list of all DE genes with $p \leq 0.01$ is attached as Supplementary Materials Tables S1-S3. The complete list of DE genes with two-fold or greater changes is shown in the attached Supplementary Materials Tables S1-S3. A subset of DE genes with high fold changes ( $>2$-fold change, $p \leq 0.01$ ) either up- or downregulated in Choice versus Standard quality grades is shown in Tables 3 and 4, respectively. A subset of DE genes with high fold changes (>2-fold change, $p \leq 0.01)$ either up- or downregulated in Choice versus Select quality grades is shown in Tables 5 and 6, respectively. Upregulated DE genes observed in samples from Standard versus Choice carcasses function in transcriptional regulation, inter- and extracellular signaling, growth, muscle metabolism, and angiogenesis (Table 3). Differentially expressed genes that were downregulated function in transcriptional regulation, amino acid transport, and metabolism (Table 4). Upregulated DE genes observed in samples from Select versus Choice carcasses function in extracellular and cytokine signaling, catalytic activity, protein binding, and positive regulation of cell migration and angiogenesis (Table 5). Differentially expressed genes that were downregulated function in anti-inflammatory activity, lipoprotein metabolism, immune response, T-cell activity, and protein catabolism (Table 4). Some of the observations are similar to those previously reported by Clark et al. [30], who examined muscle gene expression associated with increased marbling in beef cattle. Clark et al. [30] reported a 1.38-fold increase in G-protein-coupled receptor 153 (GPR153), a 1.41-fold change in the Matrix-remodeling-associated 8 [29] transcript, and a 1.88-fold increase in Pleckstrin and Sec 7 domain-containing (PSD) transcripts when comparing high-marbled vs. low-marbled beef cattle. This study found similar results, with a 3.7fold change in GPR153 and 3.08-fold change in MXRA8 and a 2.43-fold decrease in PSD, respectively, in muscle from Choice versus Standard carcasses (Supplementary Materials Table S2). Roberts et al. [31] utilized a targeted quantitative real-time PCR approach to examine gene expression in muscle. They found an initial decrease and then an increase in the expression of NADH dehydrogenase 2 (ND2) when examining muscle with no intramuscular fat transitioning to mature intramuscular fat. This study had a 7.42-fold increase in the expression of ND2 in the comparison of Standard vs. Choice muscle tissue. Similarly, Roberts et al. [31] showed a high level of expression of tissue metallopeptidase inhibitor 4 (TIMP4) in muscle early in the development of intramuscular fat with a decrease and later increased as intramuscular fat developed. This study showed a 2.6-fold increase in TIMP4 in muscle from Standard carcasses compared to Choice muscle tissue (Supplementary Materials Table S2). Lastly, Fonseca et al. [9] showed a 0.77-fold decrease in the expression of heme oxygenase 1 (HMOX1) with increasing tenderness in Nellore cattle. This study observed a similar 2-fold decrease in HMOX 1 when comparing Standard vs. Choice muscle tissue with no associated difference in tenderness. 
Table 3. Upregulated differentially expressed genes with high fold changes in Choice compared to Standard LD muscle.

\begin{tabular}{|c|c|c|c|c|}
\hline Gene ID & Gene Name & Fold Change & Corrected $p$-Value & Function \\
\hline TET1 & Tet methylcytosine dioxygenase 1 & 12.37 & 0.031 & DNA and iron binding \\
\hline ETV5 & ETS variant 5 & 9.89 & 0.045 & $\begin{array}{l}\text { Regulation of transcription, neuromuscular } \\
\text { transmission }\end{array}$ \\
\hline BRB & Brain ribonuclease & 9.89 & 0.002 & $\begin{array}{c}\text { Nucleic acid binding, endonuclease activity, } \\
\text { hydrolase activity }\end{array}$ \\
\hline DKK3 & $\begin{array}{c}\text { Dickkopf WNT signaling pathway } \\
\text { inhibitor } 3\end{array}$ & 9.89 & 0.002 & $\begin{array}{l}\text { Multicellular organism development, } \\
\text { negative regulation of WNT signaling }\end{array}$ \\
\hline BASE2 & Beta-secretase 2 & 9.28 & 0.003 & Proteolysis, protein catabolic processes \\
\hline TNFAIP2 & TNF-alpha-induced protein 2 & 8.67 & 0.008 & SNARE binding, exocytosis \\
\hline HPGD & $\begin{array}{l}\text { 5-hydroxyprostaglandin } \\
\text { dehydrogenase }\end{array}$ & 6.80 & 0.016 & Growth factor receptor signaling \\
\hline PCGF6 & Polycomb group ring finger 6 & 6.18 & 0.025 & Negative regulation of transcription \\
\hline SERPINE1 & Serpin family E member 1 & 4.93 & 0.006 & $\begin{array}{l}\text { Angiogenesis, protease binding, enzyme } \\
\text { inhibitor activity }\end{array}$ \\
\hline ANKRD2 & Ankyrin repeat domain 2 & 2.06 & 0.016 & $\begin{array}{l}\text { Protein/titin binding, skeletal muscle } \\
\text { development/differentiation }\end{array}$ \\
\hline
\end{tabular}

Table 4. Downregulated differentially expressed genes with high fold changes in Choice compared to Standard LD muscle.

\begin{tabular}{|c|c|c|c|c|}
\hline Gene ID & Gene Name & Fold Change & Corrected $p$-Value & Function \\
\hline RFC2 & Replication factor C subunit & 11.77 & 0.0008 & $\begin{array}{l}\text { DNA binding, DNA replication, Cell cycle } \\
\text { activity }\end{array}$ \\
\hline PQLC2 & PQ loop repeat containing 2 & 9.01 & 0.0003 & Amino acid transmembrane transport \\
\hline PPM1F & $\begin{array}{c}\text { Protein phosphatase, } \mathrm{Mg}^{2+} / \mathrm{Mn}^{2+} \\
\text { dependent } 1 \mathrm{~F}\end{array}$ & 8.09 & 0.0008 & $\begin{array}{l}\text { Protein dephosphorylation, positive } \\
\text { regulation of transcription, negative } \\
\text { regulation of protein kinase }\end{array}$ \\
\hline TBPL1 & TATA-box binding protein-like 1 & 4.56 & 0.027 & $\begin{array}{l}\text { DNA binding, positive regulation of } \\
\text { transcription }\end{array}$ \\
\hline GLB1 & Galactosidase beta 1 & 4.31 & 0.028 & $\begin{array}{l}\text { Carbohydrate metabolic process, hydrolase } \\
\text { activity }\end{array}$ \\
\hline INSIG2 & Insulin-induced gene & 3.9 & 0.027 & Lipid metabolic process \\
\hline GALNT11 & $\begin{array}{c}\text { Polypeptide } \\
\text { N-acetylgalactosaminyltransferase } 11\end{array}$ & 3.74 & 0.027 & $\begin{array}{c}\text { Notch binding, protein glycosylation, } \\
\text { transferase activity }\end{array}$ \\
\hline TAF7-201 & $\begin{array}{l}\text { TATA-box binding protein associated } \\
\text { factor } 7\end{array}$ & 3.07 & 0.0004 & $\begin{array}{c}\text { Negative regulation of transcription, thyroid } \\
\text { hormone signaling }\end{array}$ \\
\hline NKTR & Natural killer cell triggering receptor & 2.75 & 0.0005 & Protein folding and protein refolding \\
\hline PSMA4 & Proteasome subunit alpha 4 & 2.17 & 0.0008 & Proteolysis, protein catabolic processes \\
\hline
\end{tabular}

Table 5. Upregulated differentially expressed genes with high fold changes in Choice compared to Select LD muscle.

\begin{tabular}{|c|c|c|c|c|}
\hline Gene ID & Gene Name & Fold Change & Corrected $p$-Value & Function \\
\hline MX1 & MX1 MX dynamin-like GTPase 1 & 11.25 & $<0.000$ & $\begin{array}{l}\text { Extracellular signaling, immune response, } \\
\text { recognition of pregnancy }\end{array}$ \\
\hline CHRND & $\begin{array}{l}\text { Cholinergic receptor nicotinic delta } \\
\text { subunit }\end{array}$ & 7.59 & 0.002 & Muscle acetylcholine receptor \\
\hline UBA7 & Brain ribonuclease & 7.24 & $<0.000$ & Cytokine signaling \\
\hline RSAD2 & $\begin{array}{l}\text { Radical S-adenosyl methionine } \\
\text { domain-containing } 2\end{array}$ & 6.9 & $<0.001$ & $\begin{array}{l}\text { Iron and sulfur binding, catalytic activity, } \\
\text { protein self-association }\end{array}$ \\
\hline OAS1Z & $2^{\prime}, 5^{\prime}$-oligoadenylate synthetase 1 & 6.12 & $<0.001$ & $\begin{array}{c}\text { Cytokine signaling, neutrophil gene } \\
\text { expression }\end{array}$ \\
\hline NUDT8 & Nudix hydrolase 8 & 5.55 & 0.004 & Coenzyme A diphosphatase \\
\hline NMRAL1 & NmrA-like redox sensor 1 & 5.52 & $<0.001$ & Protein binding, nuclear signaling \\
\hline CELSR1 & $\begin{array}{c}\text { Cadherin EGF LAG seven-pass G-type } \\
\text { receptor } 1\end{array}$ & 5.42 & 0.005 & $\begin{array}{c}\text { Positive regulation of cell migration and } \\
\text { angiogenesis }\end{array}$ \\
\hline SQLE & Squalene epoxidase & 5.23 & 0.01 & $\begin{array}{l}\text { Modulator of plasma membrane lipid profile, } \\
\text { cholesterol synthesis inhibition }\end{array}$ \\
\hline BOLA-DOB & $\begin{array}{l}\text { Major histocompatibility complex, } \\
\text { class II, DO beta }\end{array}$ & 5.2 & 0.044 & Immune function, self-recognition, \\
\hline
\end{tabular}


Table 6. Downregulated differentially expressed genes with high fold changes in Choice compared to Select LD muscle.

\begin{tabular}{ccccc}
\hline Gene ID & Gene Name & Fold Change & Corrected $p$-Value & Function \\
\hline PLA2G7 & Phospholipase A2 group VII & 7.00 & & Anti-inflammatory activity, lipoprotein \\
metabolism \\
BACH2 & BTB domain and CNC homolog 2 & 6.52 & 0.01 & Innate immune response, PAX5 signaling \\
ALK & ALK receptor tyrosine kinase & 6.28 & 0.027 & Cellular signaling \\
ZNF184 & Zinc finger protein 184 & 6.02 & 0.001 & 0.01 \\
ZP2 & Zona pellucida glycoprotein 2 & 5.71 & 0.02 & Reproduction, Ca2+ transport \\
SMOX & Spermine oxidase & 5.67 & 0.05 & ROS mediation, catabolism of polyamines \\
PRDM15 & PR/SET domain 15 & 5.05 & 0.006 & Neurogenesis, epigenetic modifier \\
TNFRSF12A & TNF receptor superfamily member 12A & 4.86 & 0.016 & T-cell activity, immune function \\
CD8A & CD8a molecule & 4.61 & 0.001 & Endoplasmic reticulum function, protein \\
DNAJB14 & DNAJ heat-shock protein family & 4.53 & & \\
& (Hsp40) member B14 & & & \\
\hline
\end{tabular}

Functional analysis was run using DAVID (6.8) bioinformatics software, which revealed differences in the underlying pathways regulating muscle cell growth and proliferation. The complete list of enriched pathways and processes is shown in Supplementary Materials Table S3. A subset of significantly $(p<0.1)$ enriched KEGG pathways and gene ontology terms, including cellular components, biological processes, and molecular functions, is shown in Tables 7 and 8, respectively. Biological processes of upregulated genes are associated with signaling pathways associated with inflammation, growth, and metabolism. Furthermore, upregulated genes associated with the extracellular matrix, stem cell differentiation, and focal adhesion were observed. Biological processes of downregulated genes are associated with RNA transport, degradation, and processing of RNA along with cellular metabolism.

Table 7. Gene set enrichment analysis of KEGG Pathways, and Gene Ontology of DE genes upregulated in Choice compared to Standard LD muscle.

\begin{tabular}{|c|c|c|}
\hline KEGG Pathways & & \\
\hline Pathway Name & Count & $p$-Value \\
\hline TNF signaling pathway & 15 & $<0.001$ \\
\hline Signaling pathway regulating pluripotency of stem cells & 16 & 0.004 \\
\hline Thyroid hormone signaling pathway & 14 & 0.004 \\
\hline Neurotrophin signaling pathway & 14 & 0.009 \\
\hline Apoptosis & 8 & 0.01 \\
\hline Insulin resistance & 12 & 0.02 \\
\hline Type 2 diabetes mellitus & 7 & 0.03 \\
\hline FoxO signaling pathway & 13 & 0.03 \\
\hline Focal adhesion & 17 & 0.05 \\
\hline \multicolumn{3}{|l|}{ Gene Ontology } \\
\hline \multicolumn{3}{|l|}{ Cellular Compartment } \\
\hline Proteinaceous extracellular matrix & 27 & $<0.001$ \\
\hline Cortical actin cytoskeleton & 8 & 0.01 \\
\hline \multicolumn{3}{|l|}{ Biological process } \\
\hline Canonical Wnt signaling pathway & 13 & $<0.01$ \\
\hline Negative regulation of catalytic activity & 7 & 0.03 \\
\hline Regulation of cell migration & 17 & 0.05 \\
\hline \multicolumn{3}{|l|}{ Molecular Function } \\
\hline Endopeptidase activity & 7 & 0.03 \\
\hline Metal ion binding & 90 & 0.06 \\
\hline
\end{tabular}


Table 8. Gene set enrichment analysis of KEGG Pathways and Gene Ontology of DE genes downregulated in Choice compared to Standard LD muscle.

\begin{tabular}{|c|c|c|}
\hline \multicolumn{3}{|l|}{ KEGG Pathways } \\
\hline Pathway Name & Count & $p$-Value \\
\hline RNA transport & 24 & $<0.001$ \\
\hline RNA Degradation & 25 & $<0.001$ \\
\hline Spliceosome & 19 & 0.002 \\
\hline cGMP-PKG signaling pathway & 20 & 0.007 \\
\hline NF-kappa B signaling pathway & 13 & 0.01 \\
\hline Lysosome & 16 & 0.02 \\
\hline Basal transcription factors & 8 & 0.02 \\
\hline Metabolic pathways & 98 & 0.02 \\
\hline Vascular smooth muscle contraction & 14 & 0.04 \\
\hline \multicolumn{3}{|l|}{ Gene Ontology } \\
\hline \multicolumn{3}{|l|}{ Cellular Compartment } \\
\hline Cytoplasm & 288 & $<0.001$ \\
\hline Small-subunit processome & 8 & 0.009 \\
\hline \multicolumn{3}{|l|}{ Biological Process } \\
\hline RNA methylation & 4 & 0.002 \\
\hline Positive regulation of interferon-beta production & 7 & 0.003 \\
\hline DNA repair & 19 & 0.003 \\
\hline mRNA splicing & 16 & 0.003 \\
\hline Negative regulation of MAP kinase activity & 8 & 0.004 \\
\hline \multicolumn{3}{|l|}{ Molecular Function } \\
\hline Metal ion binding & 137 & $<0.001$ \\
\hline Nucleic acid binding & 58 & $<0.001$ \\
\hline RNA methyltransferase activity & 5 & $<0.001$ \\
\hline
\end{tabular}

Many researchers have reported that MyoD, myogenin, Myf5, and MURF 4 [32,33], along with the upregulation of the mTOR pathway [33], are necessary for increased muscle mass. Goodman et al. [34] stated that mTOR was necessary for up to $50 \%$ of the basal rates of protein synthesis. However, in this preliminary study, no increase in any of these signals was seen in muscle from carcasses that resulted in a Choice quality grade compared to Standard. One possible explanation is that the downregulation of RNA degradation or the modification of signals within the pathway leads to the stabilization of the RNA needed for the increased synthesis of muscle proteins, so there is no need to increase signaling to make more RNA. Another possible explanation is that the control of muscle growth is no longer under transcriptional control. This has been reported previously by Tao et al. [35], who reported a higher correlation between adipose tissue gene expression clusters and carcass traits than what they saw for muscle tissue gene expression [36]. Additionally, a recent review by Raza et al. [36] showed that microRNAs played a large role in the regulation of muscle growth during a similar period.

An increase in the genes associated with the extracellular matrix, stem cell differentiation, and focal adhesions would suggest there is still muscle growth occurring. The extracellular matrix is an important part of the development of muscle cells. Focal adhesions are needed to anchor the myofibrillar structure to connective tissue in the muscle to help translate the mechanical action. Flück et al. [37] reported that focal adhesion kinase (FAK) is associated with focal adhesions and is a key regulator of the focal adhesion complex. The upregulation of pathways associated with focal adhesion may result in increased FAK. Crossland and coworkers [38] reported that FAK is a key component of IGF-1 modulation in cell culture and postulated that it is a key player in muscle growth in humans. Additionally, Keady et al. [39] found that sire breed and genetic merit for carcass weight impacted the transcriptional regulation of the somatotropic axis in the muscle tissue of crossbred steers, including a greater gene expression of IGF-1 and a reduced transcript abundance of IGFBP3 in increased muscle growth potential. 
The downregulation of amino acid transport and metabolism could indicate that the muscle in the Choice carcass had reached maximum muscle growth and was in the process of moving consumed nutrients into storage as opposed to using them for growth. Energy consumed that is greater than that needed for growth or maintenance will be stored as fat.

\section{Conclusions}

As expected, steaks from Choice carcasses had a lower shear value than steaks from Select carcasses; however, there were no differences in differentially expressed genes that could be related to tenderness. Upregulated DE genes observed in samples from Standard versus Choice carcass functions were related to transcriptional regulation, inter- and extracellular signaling, growth, muscle metabolism, and angiogenesis, while downregulated DE genes were related to transcriptional regulation, amino acid transport, and metabolism. Enriched processes, including extracellular matrix, stem cell differentiation, and focal adhesions, suggest continued muscle growth in addition to fat deposition in carcasses of a higher quality grade. This explorative analysis of muscle transcript expression along with the findings of others $[35,36]$ may indicate that muscle tissue during the finishing phase is not primarily under transcriptional regulation and that the transcriptional of adipose tissue may have a more predominant role in the determination of carcass quality grade. Exploratory analysis of global muscle tissue transcriptome in Standard and Choice carcasses provides insight into muscle biochemistry, and while additional research is needed to explore the function and timing of gene expression changes, it appears to be a useful approach to providing insight and generating additional research questions and direction to improve understanding of muscle development and fat deposition.

Supplementary Materials: The following are available online at https:/ / www.mdpi.com/article/10 .3390 /ani11071910/s1, Table S1, Differentially expressed genes in Choice muscle; Table S2, Differentially expressed genes: Choice vs. Standard; Table S3, Differentially expressed genes: Select vs. Standard.

Author Contributions: B.E.: Investigation, Formal Analysis, Writing-Original Draft. M.M.: Investigation, Formal Analysis, Writing-Original Draft. J.A.B.: Conceptualization, Methodology, Formal Analysis, Resources, Writing -Original Draft, Writing-Review and Editing. J.T.: Conceptualization, Methodology, Formal Analysis, Investigation, Resources, Data Curation, Writing-Original Draft, Writing-Review and Editing, Supervision, Project administration, Funding Acquisition. All authors have read and agreed to the published version of the manuscript.

Funding: Project funded by Montana Agricultural Experiment Station and Montana State University Undergraduate Scholars Program Fellowship.

Institutional Review Board Statement: All animals received care according to the "Guide for the Care and Use of Agricultural Animals in Agricultural Research and Teaching, 3rd Edition" and under the supervision of the Fort Keogh Animal Care and Use Committee (ACUC No.: 020104-9).

Data Availability Statement: RNA-seq data can be accessed at 10.5281/zenodo.4993828.

Conflicts of Interest: The authors declare no conflict of interest.

\section{References}

1. Monson, F.; Sanudo, C.; Sierra, C. Influence of cattle breed and ageing time textural breed quality. Meat Sci. 2004, 68, 595-602. [CrossRef] [PubMed]

2. Neely, T.R.; Lorenzen, C.L.; Miller, R.K.; Tatum, J.D.; Wise, J.W.; Taylor, J.F.; Buyck, M.J.; Reagan, J.O.; Savell, J.W. Beef customer satisfaction: Role of cut, USDA quality grade, and city on in-home consumer ratings. J. Anim. Sci. 1998, 76, 1027-1033. [CrossRef] [PubMed]

3. Obuz, E.; Dikeman, M.E.; Grobbel, J.P.; Stephans, J.W.; Loughin, T.M. Beef longissimus lumborum, biceps femoris, and deep pectoralis Warner-Bratzler shear force is affected differently by endpoint temperature, cooking method, and USDA quality grade. Meat Sci. 2004, 68, 243-248. [CrossRef] [PubMed]

4. $\quad$ Emerson, M.R.; Woerner, D.R.; Belk, K.E.; Tatum, J.D. Effectiveness of USDA instrument-based marbling measurements for categorizing beef carcasses according to differences in longissimus muscle sensory attributes. J. Anim. Sci. 2013, 91, 1024-1034. [CrossRef] [PubMed] 
5. Shackleford, S.D.; Koohmaraie, M.; Whipple, G.; Wheeler, T.L.; Miller, M.F.; Crouse, J.D.; Reagan, J.O. Predictors of Beef Tenderness: Development and Verification. J. Food Sci. 1991, 56, 1130-1135. [CrossRef]

6. Tatum, J.D.; Smith, G.C.; Carpenter, Z.L. Interrelationships between marbling, subcutaneous fat thickness and cooked beef palatability. J. Anim. Sci. 1980, 54, 777-784. [CrossRef]

7. Eggen, A.; Hocquette, J.F. Genomic approaches to economic trait loci and tissue expression profiling: Application to muscle biochemistry and beef quality. Meat Sci. 2004, 66, 1-9. [CrossRef]

8. Leal-Gutiérrez, J.D.; Elzo, M.A.; Carr, C.; Mateescu, R.G. RNA-seq analysis identifies cytoskeletal structural genes and pathways for meat quality in beef. PLoS ONE 2020, 15, e0240895. [CrossRef]

9. Fonseca, L.F.; Gimenez, D.F.; dos Santos Silva, D.B.; Barthelson, R.; Baldi, F.; Ferro, J.A.; Albuquerque, L.G. Differences in global gene expression in muscle tissue of Nellore cattle with divergent meat tenderness. BMC Genom. 2017, 18, 945. [CrossRef] [PubMed]

10. Sheng, X.; Ni, H.; Liu, Y.; Li, J.; Zhang, L.; Guo, Y. RNA-seq analysis of bovine intramuscular, subcutaneous and perirenal adipose tissues. Mol. Biol. Rep. 2014, 41, 1631-1637. [CrossRef]

11. Ladeira, M.M.; Schoonmaker, J.P.; Gionbelli, M.P.; Dias, J.C.O.; Gionbelli, T.R.S.; Carvalho, J.R.R.; Teixeira, P.D. Nutrigenomics and Beef Quality: A Review about Lipogenesis. Int. J. Mol. Sci. 2016, 17, 918. [CrossRef]

12. Ladeira, M.; Schoonmaker, J.; Swanson, K.; Duckett, S.; Gionbelli, M.; Rodrigues, L.; Teixeira, P. Review: Nutrigenomics of marbling and fatty acid profile in ruminant meat. Animal 2018, 12, S282-S294. [CrossRef]

13. Liang, R.; Han, B.; Li, Q.; Yuan, Y.; Li, J.; Sun, D. Using RNA sequencing to identify putative competing endogenous RNAs (ceRNAs) potentially regulating fat metabolism in bovine liver. Sci. Rep. 2017, 7, 6396. [CrossRef] [PubMed]

14. USDA-United States Department of Agriculture. United States Standards for Grades of Carcass Beef. 2017. Available online: https:/ / www.ams.usda.gov/sites/default/files/media/CarcassBeefStandard.pdf (accessed on 26 June 2021).

15. Huang, D.W.; Sherman, B.T.; Lempicki, R.A. Bioinformatics enrichment tools: Paths toward the comprehensive functional analysis of large gene lists. Nucleic Acids Res. 2009, 37, 1-13. [CrossRef]

16. Das, S.; Shyamal, S.; Durica, D.S. Analysis of Annotation and Differential Expression Methods used in RNA-seq Studies in Crustacean Systems. Integr. Comp. Biol. 2016, 56, 1067-1079. [CrossRef] [PubMed]

17. Robinson, M.D.; Oshlack, A. A scaling normalization method for differential expression analysis of RNA-seq data. Genome Biol. 2010, 11, R25. [CrossRef] [PubMed]

18. Boles, J.A.; Kohlbeck, K.S.; Meyers, M.C.; Perz, K.A.; Davis, K.C.; Thomson, J.M. The use of blood lactate concentration as an indicator of temperament and its impact on growth rate and tenderness of steaks from Simmental $\times$ Angus steers. Meat Sci. 2015, 103, 68-74. [CrossRef]

19. Boles, J.A.; Boss, D.L.; Neary, K.I.; Davis, K.C.; Tess, M.W. Growth implants reduced tenderness of steaks from steers and heifers with different genetic potentials for growth and marbling. J. Anim. Sci. 2009, 87, 269-274. [CrossRef]

20. May, S.G.; Dolezal, H.G.; Gill, D.R.; Ray, F.K.; Buchanan, D.S. Effect of days fed, carcass grade traits, and subcutaneous fat removal on postmortem muscle characteristics and beef palatability. J. Anim. Sci. 1992, 70, 444-453. [CrossRef]

21. Kern, S.A.; Pritchard, R.H.; Blair, A.D.; Scramlin, S.M.; Underwood, K.R. The influence of growth stage on carcass composition and factors associated with marbling development in beef cattle. J. Anim. Sci. 2014, 92, 5275-5284. [CrossRef] [PubMed]

22. Nurnberg, K.; Wegner, J.; Ender, K. Factors influencing fat composition in muscle and adipose tissue of farm animals. Live Prod. Sci. 1998, 56, 145-156. [CrossRef]

23. Robelin, J. Growth of adipose tissues in cattle; partitioning between depots, chemical composition and cellularity. Rev. Live Prod. Sci. 1986, 14, 349-364. [CrossRef]

24. Legako, J.F.; Brooks, J.C.; O’Quinn, T.G.; Hagan, T.D.J.; Polkinghorne, R.; Farmer, L.J.; Miller, M.F. Consumer palatability scores and volatile beef flavor compounds of five USDA quality grades and four muscles. Meat Sci. 2015, 100, 291-300. [CrossRef]

25. Smith, G.C.; Carpenter, Z.L.; Cross, H.R.; Murphey, C.E.; Abraham, H.C.; Savell, J.W.; Davis, G.W.; Berry, B.W.; Parrish, F.C., Jr. Relationship of USDA marbling groups to palatability of cooked beef. J. Food Qual. 1985, 7, 289-308. [CrossRef]

26. Bratcher, C.L.; Johnson, D.D.; Littell, R.C.; Gwartney, B.L. The effects of quality grade, aging, and location within muscle on Warner-Bratzler shear force in beef muscles of locomotion. Meat Sci. 2005, 70, 279-284. [CrossRef]

27. Gruber, S.L.; Tatum, J.D.; Scanga, J.A.; Chapman, P.L.; Smith, G.C.; Belk, K.E. Effects of postmortem aging and USDA quality grade on Warner-Bratzler shear force values of seventeen individual beef muscles. J. Anim. Sci. 2006, 84, 3387-3396. [CrossRef] [PubMed]

28. Marino, R.; Albenzio, M.; dell Malva, A.; Santillo, A.; Loizzp, P.; Sevi, A. Proteolytic pattern of myofibrillar protein and meat tenderness as affected by breed and aging time. Meat Sci. 2013, 95, 281-287. [CrossRef] [PubMed]

29. Purchas, R.W.; Aungsupakorn, R. Further investigations into the relationship between ultimate $\mathrm{pH}$ and tenderness for beef samples from bulls and steers. Meat Sci. 1993, 34, 163-178. [CrossRef]

30. Clark, D.L.; Boler, D.D.; Kutzler, L.W.; Jones, K.A.; McKeith, F.K.; Killefer, J.; Carr, T.R.; Dilger, A.C. Muscle gene expression associated with increased marbling in beef cattle. Anim. Biotech. 2011, 22, 51-63. [CrossRef] [PubMed]

31. Roberts, S.L.; Lancaster, P.A.; DeSilva, U.; Horn, G.W.; Krehbiel, C.R. Coordinated gene expression between skeletal muscle and intramuscular adipose tissue in growing beef cattle. J. Anim. Sci. 2015, 93, 4302-4311. [CrossRef] [PubMed]

32. Le Grand, F.; Rudnicki, M.A. Skeletal muscle satellite cells and adult myogenesis. Curr. Opin. Cell Biol. 2007, 19, 628-633. [CrossRef] 
33. Zammit, P.S. Function of the myogenic regulatory factors Myf5, MyoD, Myogenin and MRF4 in skeletal muscle, satellite cells and regenerative myogenesis. In Seminars in Cell E Developmental Biology; Academic Press: Cambridge, MA, USA, 2017; Volume 72, pp. 19-32.

34. Goodman, C. The Role of mTORC1 in Mechanically-Induced Increases in Translation and Skeletal Muscle Mass. J. Appl. Phys. 2019, 127, 581-590. [CrossRef]

35. Flück, M.; Carson, J.A.; Gordon, S.E.; Ziemiecki, A.; Booth, F.W. Focal adhesion proteins FAK and paxillin increase in hypertrophied skeletal muscle. Am. J. Physiol. 1999, 277, C152-C162. [CrossRef] [PubMed]

36. Crossland, H.; Kazi, A.A.; Lang, C.H.; Timmons, J.A.; Pierre, P.; Wilkinson, D.J.; Smith, K.; Szewczyk, N.J.; Atherton, P.J. Focal adhesion kinase is required for IGF-I-mediated growth of skeletal muscle cells via a TSC2/mTOR/S6K1-associated pathway. Am. J. Physiol. Endocrinol. Metab. 2013, 15, E183-E193. [CrossRef] [PubMed]

37. Tao, X.; Liang, Y.; Yang, X.; Pang, J.; Zhong, Z.; Chen, X.; Yang, Y.; Zeng, K.; Kang, R.; Lei, Y.; et al. Transcriptomic profiling in muscle and adipose tissue identifies genes related to growth and lipid deposition. PLoS ONE 2017, 6, e0184120. [CrossRef] [PubMed]

38. Raza, S.H.A.; Kaster, N.; Khan, R.; Abdelnour, S.A.; El-Hack, M.E.A.; Khafaga, A.F.; Taha, A.; Ohran, H.; Swelum, A.A.; Schreurs, N.M.; et al. The Role of MicroRNAs in Muscle Tissue Development in Beef Cattle. Genes 2020, 11, 295. [CrossRef]

39. Keady, S.M.; Kenny, D.A.; Keane, M.G.; Waters, S.M. Effect of sire breed and genetic merit for carcass weight on the transcriptional regulation of the somatotropic axis in longissimus dorsi of crossbred steers. J. Anim. Sci. 2011, 89, 4007-4016. [CrossRef] 